\title{
Correction to: Exploration of motivation to participate in a study of cancer-related cognitive impairment among patients with newly diagnosed aggressive lymphoma: a qualitative sub-study
}

\author{
Priscilla Gates $^{1,2}$ (D) $\cdot$ Haryana Dhillon $^{3}$ D $\cdot$ Karla Gough $^{2,4}$ (D) Carlene Wilson $^{5,6}$ (D) $\cdot$ Eliza Hawkes $^{1,7}$ (D) \\ Lindsay Scudder ${ }^{1} \cdot$ Tania Cushion $^{1} \cdot$ Meinir Krishnasamy ${ }^{8,9,10}$ (i)
}

Published online: 18 September 2021

(c) The Author(s) 2021

\section{Correction to: Supportive Care in Cancer https://doi.org/10.1007/s00520-021-06527-9}

The article "Exploration of motivation to participate in a study of cancer-related cognitive impairment among patients with newly diagnosed aggressive lymphoma: a qualitative sub-study", written by Gates, P., Dhillon, H., Gough, K., Wilson, C., Hawkes, E., Scudder, L., Cushion, T., Krishnasamy, M., was originally published electronically on the publisher's internet portal on 08 September 2021 without open access.
With the author(s)' decision to opt for Open Choice the copyright of the article changed on 10 September 2021 to (C) The Author(s) 2021 and the article is forthwith distributed under a Creative Commons Attribution 4.0 International License, which permits use, sharing, adaptation, distribution and reproduction in any medium or format, as long as you give appropriate credit to the original author(s) and the source,
The original article can be found online at https://doi.org/10.1007/ s00520-021-06527-9

Priscilla Gates

priscilla.gates@austin.org.au

Haryana Dhillon

haryana.dhillon@sydney.edu.au

Karla Gough

karla.gough@petermac.org

Carlene Wilson

carlene.wilson@austin.org.au

Eliza Hawkes

eliza.hawkes@austin.org.au

Lindsay Scudder

lindsay.scudder@austin.org.au

Tania Cushion

tania.cushion@austin.org.au

Meinir Krishnasamy

meinir.krishnasamy@petermac.org

1 Department of Clinical Haematology, Austin Health, Melbourne, VIC, Australia
2 Department of Nursing, Faculty of Medicine, The University of Melbourne, Dentistry \& Health Sciences, Melbourne, VIC, Australia

3 Faculty of Science, School of Psychology, Centre for Medical Psychology \& Evidence-Based Decision-Making, The University of Sydney, Sydney, NSW, Australia

4 Department of Health Services Research, Peter MacCallum Cancer Centre, Melbourne, VIC, Australia

5 Olivia Newton-John Cancer Wellness and Research Centre, Austin Health, Melbourne, VIC, Australia

6 School of Psychology and Public Health, LaTrobe University, Melbourne, VIC, Australia

7 Faculty of Medicine, The University of Melbourne, Dentistry \& Health Sciences, Melbourne, VIC, Australia

8 Cancer Nursing Research Group, Department of Nursing/Centre for Cancer Research, School of Health Sciences, Faculty of Medicine, Dentistry and Health Sciences, University of Melbourne, The University of Melbourne, Melbourne, VIC, Australia

9 Academic Nursing Unit, Peter MacCallum Cancer Centre, Melbourne, VIC, Australia

10 Research and Education Nursing, Victorian Comprehensive Cancer Centre, Melbourne, VIC, Australia 
provide a link to the Creative Commons licence, and indicate if changes were made. The images or other third party material in this article are included in the article's Creative Commons licence, unless indicated otherwise in a credit line to the material. If material is not included in the article's Creative Commons licence and your intended use is not permitted by statutory regulation or exceeds the permitted use, you will need to obtain permission directly from the copyright holder. To view a copy of this licence, visit http://creativecommons. org/licenses/by/4.0.

The original articles has been corrected.

Open Access This article is licensed under a Creative Commons Attribution 4.0 International License, which permits use, sharing, adaptation, distribution and reproduction in any medium or format, as long as you give appropriate credit to the original author(s) and the source, provide a link to the Creative Commons licence, and indicate if changes were made. The images or other third party material in this article are included in the article's Creative Commons licence, unless indicated otherwise in a credit line to the material. If material is not included in the article's Creative Commons licence and your intended use is not permitted by statutory regulation or exceeds the permitted use, you will need to obtain permission directly from the copyright holder. To view a copy of this licence, visit http://creativecommons. org/licenses/by/4.0/.

Publisher's note Springer Nature remains neutral with regard to jurisdictional claims in published maps and institutional affiliations. 